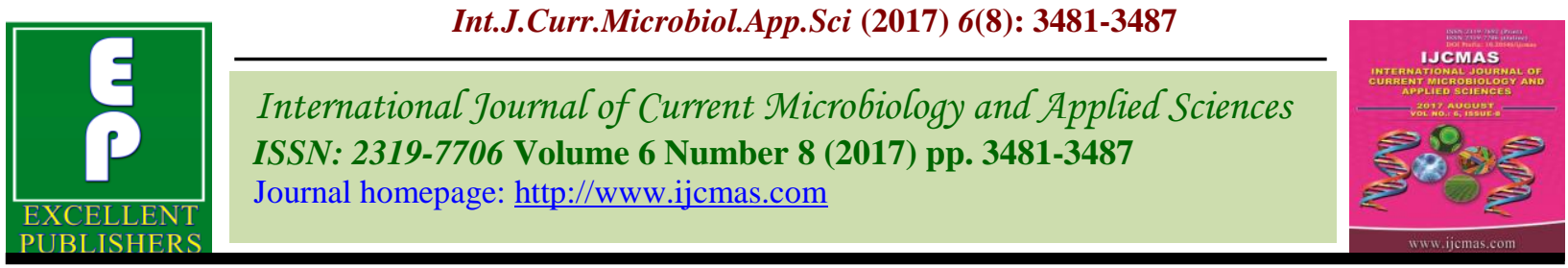

Original Research Article

https://doi.org/10.20546/ijcmas.2017.608.417

\title{
Development of Electronic Metering Mechanism for Precision Planting of Seeds
}

\author{
Shankha Koley ${ }^{1}$, Y.C. Bhatt ${ }^{2}$, Gajendra Singh ${ }^{1 *}$, Sunil Joshi ${ }^{2}$ and H. K. Jain ${ }^{2}$ \\ ${ }^{1}$ Indian Institute of Technology, Kharagpur, India \\ ${ }^{2}$ CTAE, MPUAT, Udaipur-313001, Rajasthan, India \\ *Corresponding author
}

\section{A B S T R A C T}

\begin{tabular}{|l|}
\hline Key w o r d s \\
Precision, \\
Proximity sensor, \\
Microcontroller. \\
\hline Article Info \\
\hline $\begin{array}{l}\text { Accepted: } \\
\text { 27 June } 2017 \\
\text { Available Online: } \\
\text { 10 August } 2017\end{array}$ \\
\hline
\end{tabular}

\section{Introduction}

Precision agriculture is the application of technologies and principles to manage spatial and temporal variability associated with all aspects of agricultural production for the purpose of improving crop performance and environmental quality. Success in precision agriculture is related to how well it can be applied to assess, manage, and evaluate the space-time continuum in crop production.

This theme was used here to assess the current and potential capabilities of precision agriculture. The precision planting of crops is progressing in the country, however there is no indigenous precision planting machines available in the country.
Some imported substitutes are available but being too costly are beyond the reach of common farmers. For crop production, seeds are normally required to be sown in the well prepared seed bed, maintaining row to row and plant to plant spacing. It is also required to drop the seed at desired depth for perfect germination. Various types of planters and seed drills have been developed but the problem still persists, like the missing of seeds, over filling, etc. Electronic planters work with a sensor based electronic metering system, which adds precision to the work. The sensor system incorporated in the metering unit helps in proper metering of seeds and 
maintains the seed to seed spacing, resulting in minimization of losses. The seed rate can be easily controlled with the rpm controller and can be used for a variety of seeds with a change in the seed metering plate. Previously various effort has been done to implement precision in the work by introducing electronics and sensors, Drake 1993 described the development of a two row-planting machine mounted on a $100 \mathrm{hp}$ four-wheel drive tractor.

The planter incorporates electronic programming for spacing and fertilizer application. Durairaj et al., (1994) developed a bullock drawn seed drill with a simple electronic metering system. It had an electronically controlled check valve system that facilitated precision planting of seeds. Field tests indicated negligible variation in plant spacing from the required spacing and seed damage was minimum with an acceptable germination percentage and crop stand.

Rehman and Singh 2002 developed a sensor for seed flow from seed metering mechanism. A sensor based on a light interference technique had been developed for sensing the seed flow from the metering mechanism of the planter. Aware, et al., Aug \& Nov 2008 in the metering unit of planters, by introducing LED systems for metering systems. Karthikeyan (2004). But the problems like slippage and skidding of ground wheel still persists. So keeping these points in view a project was undertaken to develop an electronic metering unit which would be devoid of ground wheel and mechanical transmission. Li et al., (2013) the development of precision seeding technique, precision seeding has become the main feature and developing direction of modern seeding technologies. Precision seeding can save seeds and effectively control the sowing depth, sowing densities and the sowing distance. According to statics, the output of precision seeding increases by 10 per cent 30 per cent compared with that of the conventional drill. V.V. Aware 2014 A microprocessor based electronic metering mechanism was design and developed for three row planter to meter the cowpea seeds. The previously developed mechanical metering mechanism exhibited various losses in mechanical linkages and hence proved to be less precise. The metering mechanism was based on the op to electric rotary sensing. The input was given to the micro controller in the form of electric pulses from the sensor and the switches, which defined the spacing of the seed. The performance of developed planter was tested in the laboratory. For the given input of $15 \mathrm{~cm}$, the output seed spacing obtained was $16.2 \mathrm{~cm}$.

\section{Materials and Methods}

\section{Construction of Electronic Metering Mechanism}

An electronic metering unit was developed by the use of inclined plate seed metering mechanism. The hopper was fabricated by using a MS sheet of $3 \mathrm{~mm}$ thickness. A $46 \mathrm{~cm}$ $\times 20 \mathrm{~cm}$ MS sheet was bent at an angle of $85^{\circ}$ to form the base. Another two MS sheet, triangular in shape of base $30 \mathrm{~cm}$ and height $23 \mathrm{~cm}$ were welded from sides to form the complete hopper. A circular hole of $18 \mathrm{~cm}$ was cut to set the metering unit. Another MS sheet of $23 \mathrm{~cm} \times 22 \mathrm{~cm}$ was set over the opening to guide the seed into the metering unit.

The number of grooves required was calculated by selecting the optimum speed of rotation of metering plate as $60 \mathrm{rpm}$, as above that the seeds gain enough of kinetic energy, problems of higher cell fill and breakage of seeds occur. The speed of operation for planter was limited to $2.5 \mathrm{~km} / \mathrm{h}$. The 
dimensions of the cells were as follows, Length- $1.5 \mathrm{~cm}$, Breadth- $0.6 \mathrm{~cm}$, Thickness$0.6 \mathrm{~cm}$, No of cells- 8 . The metering plates were rotated by the use of a variable speed, high torque DC motor. The speed of the motor was taken to a maximum range of 100 rpm so that maximum torque can be obtained. The speed of the motor was made adjustable by the use of a $100 \Omega, \quad 150$ Watt potentiometer. The metering unit was devoid of ground wheel and chain and sprocket systems. In this metering unit, the purpose of ground wheel was resolved by the use of a proximity sensor. The sensor senses the RPM of the rear wheel of the tractor and transmits the impulse to the microcontroller.

The microcontroller was so programmed that it reduces the rpm with a decrease in tractor speed and vice versa. By this method seeds can be efficiently metered and planted with ease. The complete flow chart of working and the circuit diagram of the electronic unit are shown in figures 1 and 2, respectively.

\section{Experimental Operating procedure}

The electronic metering unit was mounted over a grease belt $3555 \mathrm{~mm}$ long and the tests were carried out. The grease belt was mounted on two rollers separated by a distance of $3235 \mathrm{~mm}$. The complete setup is shown in figure 3.

The rollers were driven by a $1 \mathrm{hp}$ variable speed DC motor whose speed was varied to control the forward speed. The greased belt was driven at three speed levels of $2 \mathrm{~km} / \mathrm{h}$, $2.5 \mathrm{~km} / \mathrm{h}$ and $3 \mathrm{~km} / \mathrm{h}$. The motor was rotated at three levels of 40, 50 and $60 \mathrm{rpm}$. The hopper after filling up with seeds was run for a particular time interval of half a minute and the readings were noted. The seed to seed spacing, seed rate and seed breakage were measured. The experimental parameters are presented in table 1 .

\section{Results and Discussion}

Laboratory test were carried out to determine the seed to seed spacing and seed rate of the developed metering mechanism. Tests were carried out on greased seed belt at different motor rpm and forward speed. Seed rate for ground nut was considered as $110-112 \mathrm{~kg} / \mathrm{ha}$.

It was observed that the average seed to seed spacing was 10.1, 8.01 and $6.6 \mathrm{~cm}$ respectively at travel speed of $2 \mathrm{Km} / \mathrm{h}$ of metering plate 1 for 40,50 and $60 \mathrm{rpm}$. The figure 4 shows the seeds dropped over the seed belt.

It was observed that the average seed to seed to seed spacing was $12.62,10.01,8.26 \mathrm{~cm}$ respectively a travel speed of $2.5 \mathrm{~km} / \mathrm{h}$ of metering plate 1 for 40, 50 and $60 \mathrm{rpm}$ and an average seed to seed spacing of $15.15,12.01$ and $10.01 \mathrm{~cm}$ respectively at travel speed of 3 $\mathrm{km} / \mathrm{h}$ of metering plate 1 for 40,50 and 60 rpm. It was observed that with an increase in rpm at a constant speed the seed to seed spacing decreased and shown in figure 5 (Anantachar and Guruswamy, 2009). The seed to seed spacing decreased due to the fact that with an increase in rpm and a constant forward speed the seeds dropped per unit length increased and for the same reason the seed rate increased

It was observed that the average seed rate was $110,138.70$ and $168.55 \mathrm{~kg} / \mathrm{ha}$ respectively at travel speed of $2 \mathrm{Km} / \mathrm{h}$ of metering plate 1 for 40, 50 and $60 \mathrm{rpm}$. It was observed that the average seed rate was 88.04, 111, 134.51 $\mathrm{kg} / \mathrm{ha}$ respectively at travel speed of $2.5 \mathrm{~km} / \mathrm{h}$ of metering plate 1 for 40,50 and $60 \mathrm{rpm}$ and an average seed rate of $73.30,91.30,111$ $\mathrm{kg} / \mathrm{ha}$ respectively at travel speed of $3 \mathrm{~km} / \mathrm{h}$ of metering plate 1 for 40,50 and $60 \mathrm{rpm}$. It was observed that with an increase in rpm at a constant speed the seed rate increased. The breakage of seeds was found maximum with 
plate 1 at $2 \mathrm{~km} / \mathrm{h}$ forward speed with $60 \mathrm{rpm}$ and plate 2 at $2 \mathrm{~km} / \mathrm{h}$ at $40 \mathrm{rpm}$. The data was analyzed in terms of ANOVA on the effect of metering plate, travel speed and rpm on seed to seed spacing, seed rate and breakage of seeds. The result showed that plate 1 gives better seed to seed spacing than metering plate 2 as in table 2 .

Table.1 Variables for testing of electronic metering mechanism

\begin{tabular}{clcl}
\hline Sl. No. & Parameters & No of levels & Level Values \\
\hline & Independent Variables & 3 & $2,2.5,3$ (Ground nut) \\
1 & Speed $(\mathrm{km} / \mathrm{h})$ & 3 & $40,50,60$ (Groundnut) \\
2 & Rotation of seed plate (rpm) & 2 & Plate 1,2 \\
3 & Seed plate & & \\
& Dependent Variables & & \\
1 & Seed to seed spacing (cm) & & \\
2 & Seed Rate $(\mathrm{kg} / \mathrm{ha})$ & & \\
3 & Seed Damages (per cent) & & \\
\hline
\end{tabular}

Table.2 Effect of metering plates, speed and motor rpm on seed to seed spacing, seed rate, seed breakage for groundnut seed

\begin{tabular}{lccc}
\hline \multicolumn{1}{c}{ Treatment } & Spacing & Seed Rate & Seed Breakage \\
\hline A1: Metering Plate 1 & 10.33 & 113.832 & 1.556 \\
A2: Metering Plate 2 & 10.82 & 108.583 & 1.556 \\
SE(m) & 0.035 & 0.337 & 0.176 \\
CD 5\% & 0.102 & 0.967 & NS \\
B1: Forward speed 2km/h & 8.436 & 135.666 & 1.500 \\
B2: Forward speed 2.5km/h & 10.590 & 108.179 & 1.333 \\
B3: Forward speed 3km/h & 12.722 & 89.777 & 1.833 \\
SE(m) & 0.043 & 0.413 & 0.215 \\
CD 5\% & 0.124 & 1.184 & $\mathrm{NS}$ \\
C1: motor rpm 40 rpm & 12.959 & 88.205 & 2.000 \\
C2: motor rpm 50 rpm & 10.188 & 112.071 & 1.000 \\
C3: motor rpm 60 rpm & 8.600 & 133.346 & 1.667 \\
SE(m) & 0.043 & 0.413 & 0.215 \\
CD 5\% & 0.124 & 1.184 & 0.617 \\
\hline
\end{tabular}

Table.3 Interaction effects of speed and motor rpm on spacing, seed rate and seed breakage for groundnut seed

\begin{tabular}{cccc}
\hline Treatment & Spacing & Seed Rate & Seed Breakage \\
\hline $\mathrm{B}_{1} \mathrm{C}_{1}$ & 10.325 & 107.665 & 2.500 \\
$\mathrm{~B}_{1} \mathrm{C}_{2}$ & 8.180 & 135.888 & 0.500 \\
$\mathrm{~B}_{1} \mathrm{C}_{3}$ & 6.802 & 163.443 & 1.500 \\
$\mathrm{~B}_{2} \mathrm{C}_{1}$ & 13.048 & 85.247 & 1.500 \\
$\mathrm{~B}_{2} \mathrm{C}_{2}$ & 10.148 & 109.512 & 0.500 \\
$\mathrm{~B}_{2} \mathrm{C}_{3}$ & 8.573 & 129.778 & 2.000 \\
$\mathrm{~B}_{3} \mathrm{C}_{1}$ & 15.503 & 71.703 & 2.000 \\
$\mathrm{~B}_{3} \mathrm{C}_{2}$ & 12.237 & 90.813 & 2.000 \\
$\mathrm{~B}_{3} \mathrm{C}_{3}$ & 10.425 & 106.815 & 1.500 \\
$\mathrm{SEm} \pm$ & 0.075 & 0.715 & 0.373 \\
$\mathrm{CD} 5 \%$ & 0.215 & 2.051 & $\mathrm{NS}$ \\
\hline
\end{tabular}


Fig.1 Flow chart of the electronic circuit

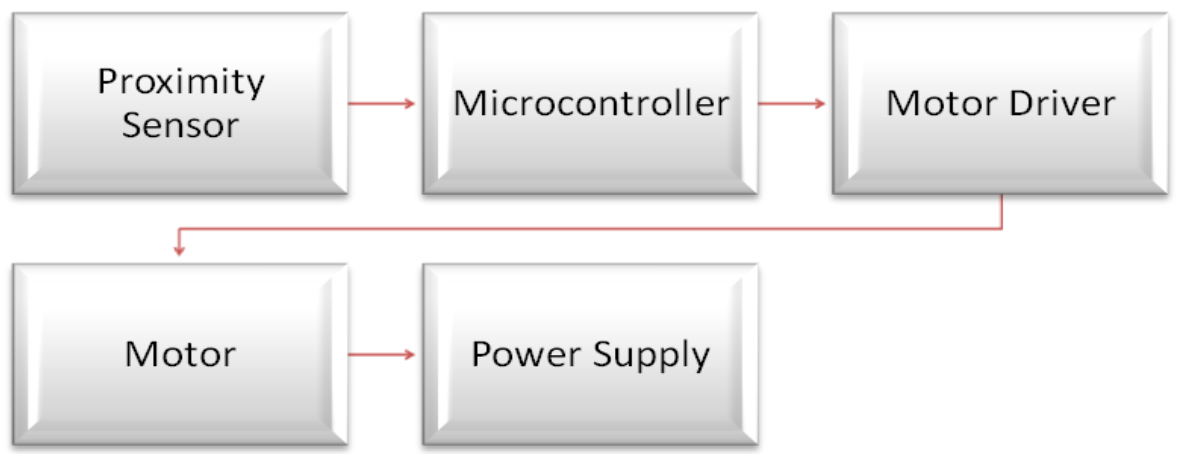

Fig.2 Electronic circuit diagram for metering mechanism

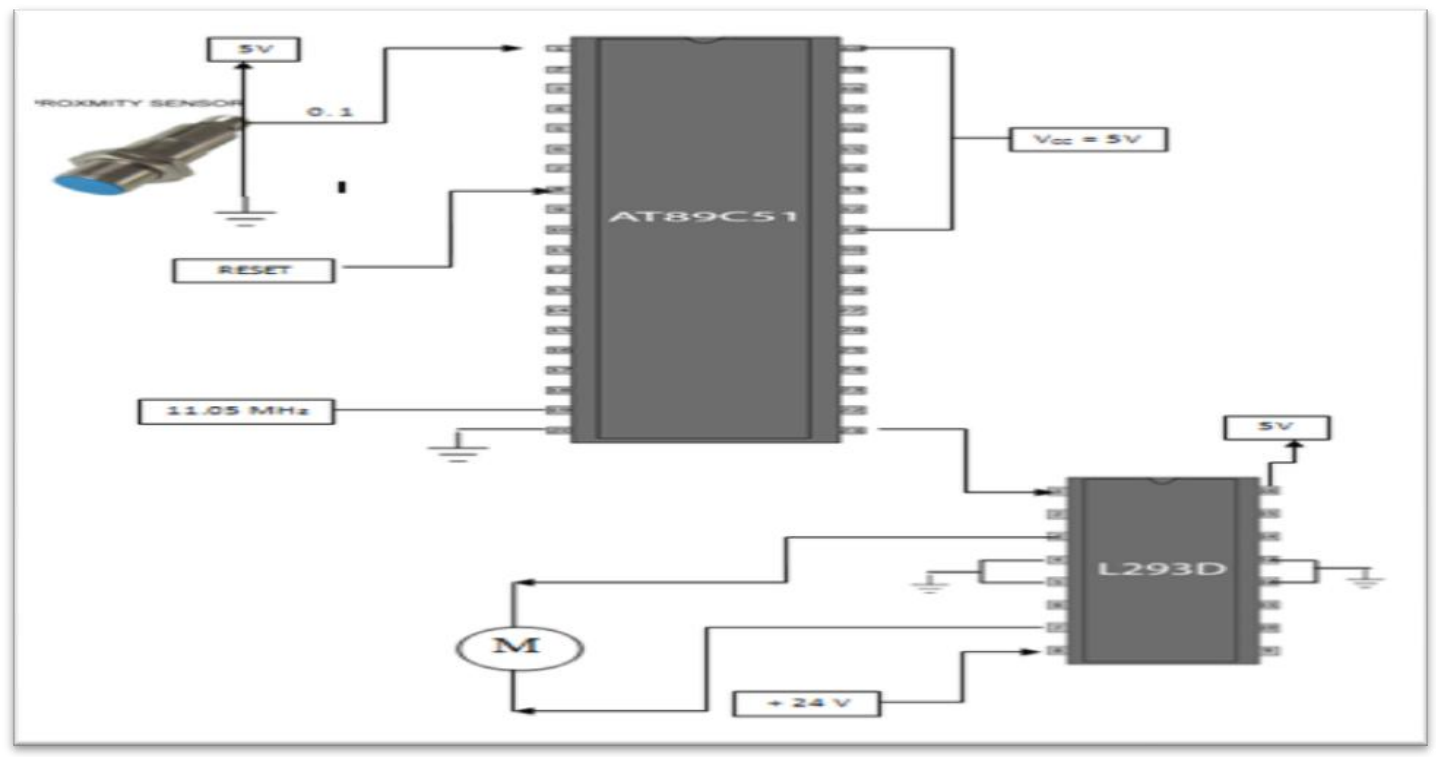

Fig.3 Laboratory setup

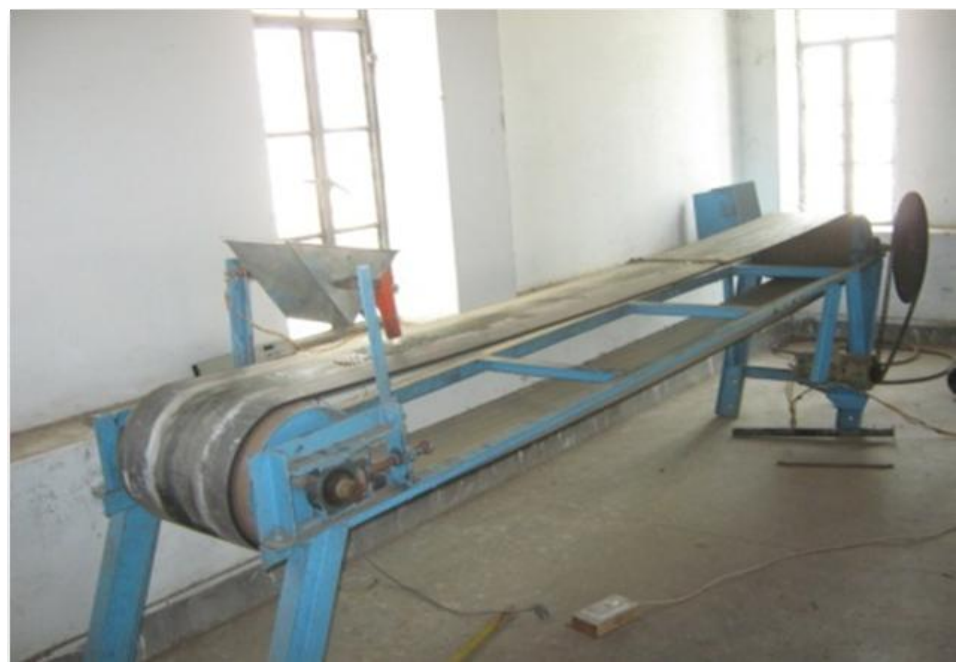


Fig.4 Groundnut seeds on grease belt

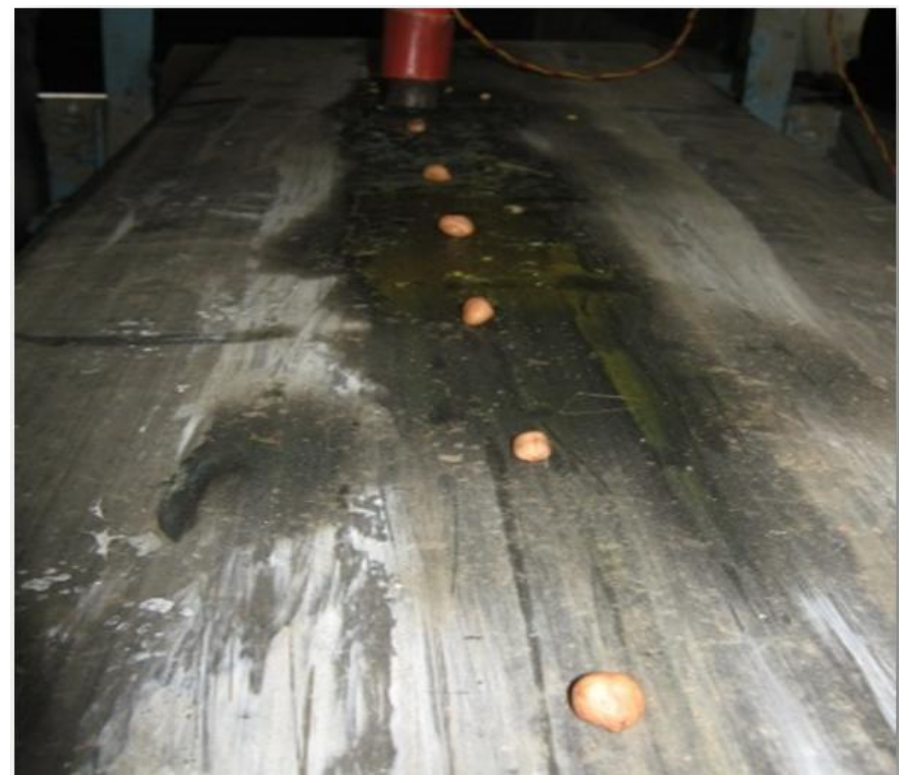

Fig.5 Seed to seed spacing and seed rate variation of ground nut at various rpm and forward speed
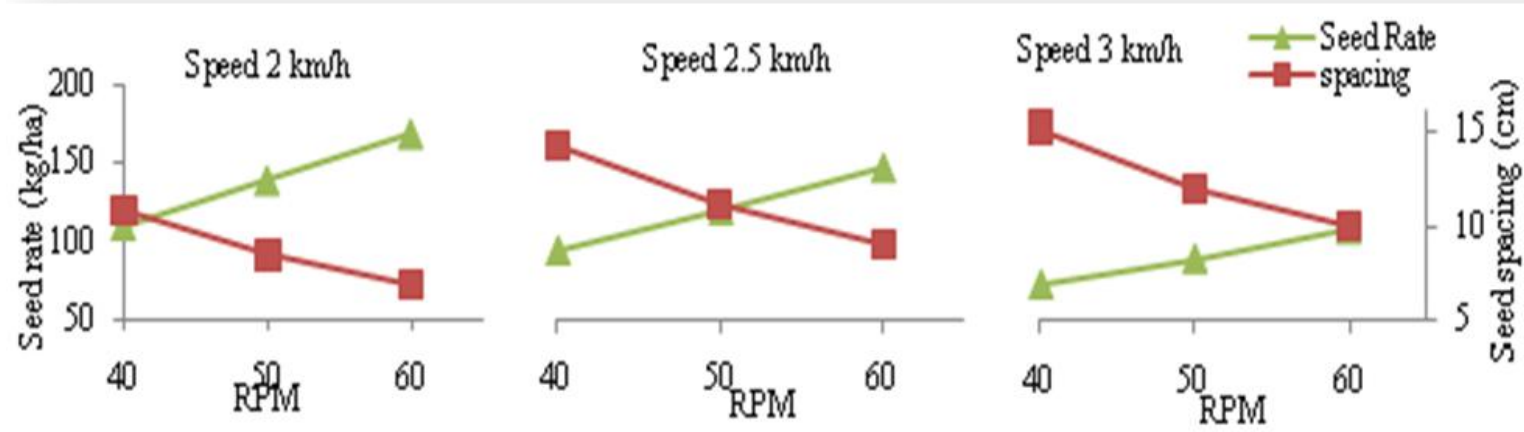

There was significant increase in seed to seed spacing with an increase in rpm of metering unit. The increase in rpm from 40 to $60 \mathrm{had}$ increased the seed to seed spacing by 50.80 per cent and decreased the seed rate by 51 per cent. The seed to seed spacing was significantly influenced by the forward speed. The seed to seed spacing was lower at $3 \mathrm{~km} / \mathrm{h}$ than at $2 \mathrm{~km} / \mathrm{h}$. The results depict that the seed rate was significantly lower at plate 2 than plate 1. Interaction effect of rpm and speed is presented in table 3 . The seed to seed spacing was seen minimum of $6.802 \mathrm{~cm}(\mathrm{rpm}$ 40 and $3 \mathrm{~km} / \mathrm{h}$ ) in comparison to a maximum of $15.503 \mathrm{~cm}(60 \mathrm{rpm}$ and $2 \mathrm{~km} / \mathrm{h})$. The interaction had significant influence on seed to speed spacing. The seed rate has a maximum value of $163.44 \mathrm{~kg} / \mathrm{ha}(40 \mathrm{rpm}$ and $3 \mathrm{~km} / \mathrm{h}$ ) in comparison to a minimum value of $71.7 \mathrm{~kg} / \mathrm{ha}$ (60 rpm and $2 \mathrm{~km} / \mathrm{h}$ ).

The interaction table suggests that it had a significant influence on the change of seed rate of groundnut seeds. The optimum condition for sowing of groundnut was found to be $50 \mathrm{rpm}$ of metering plate speed at a forward speed of $2.5 \mathrm{~km} / \mathrm{h}$. The seed breakage was also found low at this combination. 
The designed unit was run in the laboratory conditions and it was concluded that with an increase in conveyor belt speed, the rpm of the motor in the metering unit increased and vice versa. The seed to seed spacing was found to decrease with an increase in metering plate speed and the seed rate increased with the increase in metering plate rpm. The optimum metering plate speed with the forward speed was found to be $50 \mathrm{rpm}$ at a forward speed $2.5 \mathrm{~km} / \mathrm{h}$. The seed breakage was found to be minimum at a lower metering plate rpm.

\section{References}

Anantachar, M., and Guruswamy, T. 2010. Neural network prediction of performance parameters of an inclined plate seed metering device and its reverse mapping for the determination of optimum design and operational parameters, Computers and Electronics in Agriculture, Vol. 72(2).

Aware, V.V., and Aware S.V. (2014). Development of microprocessor based electronic metering mechanism for seed - an approach. Engg. \& Tech. in India, 5 (1\&2): 26-31.

Aware, V.V., Aware S V; Nalawade S M; Mane D M and Patil R P. 2008. Development of proximity distance sensor based electronic metering mechanism for three rows planter 2008 Agriculture Update, Vol. 3 No. 3\&4: 296-299.

Drake Aranda, F., 1993. Mechanized afforestation in Chile. Document
Tecnico Chile Forestal. No.75 pp.; Publication included in Chile Forestal No. 210.

Durairaj, C.D., Balasubramanian, C. and Swaminathan, K.R. 1994. A precision planter with electronic metering. Agricultural Mechanization in Asia, Africa and Latin America. 25(3): 17-18.

Garcia Kito, and Wang X L. 1997. Computer based optimal control of seeding rate based on travel speed and seed signals. Journal of Japanese Society of Agricultural Machinery. 59(6) 93-101

Gupta, C.P., and Ahmmed S. 1994. A manually-operated electrostatic planter for small seeds. Agricultural mechanization in Asia Africa and Latin America 25(2):554-583.

Karthikeyan, 2004. Developed an electronic seed monitoring system for planters. An un-published M. Tech Thesis, Department of Agricultural and Food Engineering. IIT Kharagpur

Li, Z.Q., Yu, J.Q., Feng, Z.R., et al., 2013. Simulation and performance analysis of a soybean seed metering device using discrete element method. Sensor Letters, 11(6): 1217-1222.

Raheman, H., and Singh, U. 2002. A sensor for seed flow from seed metering mechanism. Available at http://www.ieindia.org/pulbiah/ag/ 0603/june03ag2.pdf

Varshney, A.C., Tiwari P S; Narang S and Metha C R 2004. Data Book for Agricultural Machinery Design, CIAE publication, Bhopal

\section{How to cite this article:}

Shankha Koley, Y.C. Bhatt, Gajendra Singh, Sunil Joshi and Jain, H.K. 2017. Development of Electronic Metering Mechanism for Precision Planting of Seeds. Int.J.Curr.Microbiol.App.Sci. 6(8): 3481-3487. doi: https://doi.org/10.20546/ijcmas.2017.608.417 